\title{
Finding and Creating Spaces of Innovation
}

\author{
Maggi Savin-Baden ${ }^{1}$ (D) Alison MacKenzie ${ }^{2}$ (D)
}

Accepted: 6 October 2021/ Published online: 18 October 2021

(ᄋ) The Author(s), under exclusive licence to Springer Nature Switzerland AG 2021

Keywords Problem-based learning · Qualitative research · Qualitative research synthesis · Digital afterlife · Postdigital · Postdigital humans · Virtual human

\section{Introduction}

Maggi Savin-Baden is a Professor of Higher Education Research at the University of Worcester where, for the past 20 years, she has pioneered research on the use of problem-based learning, an interest which began serendipitously when a colleague at Brunel University suggested they develop courses in this area. She obtained her Masters in 1989 and then her PhD at The University of London in 1996 and followed this with an MSc in E-learning at the University of Edinburgh in 2010. Her range of academic interests extends from problem-based learning, qualitative research methods to the postdigital. She has collaborated with several people over the course of her academic career, stimulating, provoking and extending debates in, for example, digital afterlife and the constitution of the virtual human.

Maggi has an impressive publication record. To date, she has published 21 books, 2 guides, over 60 peer reviewed articles, numerous book chapters and reports. Her first book was Problem-based Learning in Higher Education: Untold Stories (Savin-Baden 2000), subsequently publishing a further six books on the theme. More recently, Maggi has published Threshold Concepts in Problem-based Learning (Savin-Baden and Tombs 2018), Virtual Humans: Today and Tomorrow (Burden and Savin-Baden 2019), Digital Afterlife: Death Matters in a Digital Age (Savin-Baden and Mason-Robbie 2020) and AI for Death and Dying (Savin-Baden 2021a). In Postdigital Science

Alison MacKenzie

A.Mackenzie@qub.ac.uk

Maggi Savin-Baden

m.savinbaden@worc.ac.uk

1 School of Education, University of Worcester, Henwick Grove, Worcester WR2 6AJ, UK

2 School of Social Sciences, Education and Social Work, Queen's University, Belfast BT7 1HL, UK 
and Education book series ${ }^{1}$ she recently published Postdigital Humans: Transitions, Transformations and Transcendence (Savin-Baden 2021b), which inspired this interview.

In 2014, Maggi became an Extraordinary Professor at Stellenbosch University, South Africa; in May 2011, she was Routledge author of the month; was awarded a National Teaching Fellowship 2008-2012 and has been Senior Fellow of the Higher Education Academy since 2013. She serves on the editorial boards of Postdigital Science and Education and the International Journal of Medical Education, ${ }^{2}$ as well as regularly reviewing for quartile journals, including Teachers College Record ${ }^{3}$ and Studies in Higher Education. ${ }^{4}$

Away from academic life, Maggi is a keen climber, snowboarder, cold-water swimmer, triathlete and half iron-woman athlete.

\section{About the Conversation}

In April 2021, Maggi Savin-Baden published her edited book, Postdigital Humans: Transitions, Transformations and Transcendence (Savin-Baden 2021b), in Postdigital Science and Education book series. To extend this important dialogue about contemporary transformations of human nature beyond the book, Petar Jandrić invited Alison MacKenzie to interview Maggi. The interviews took place in April and July 2021.

\section{From Problem-Based Learning to the Postdigital Human}

Alison MacKenzie (AMK): Tell me a bit about yourself in career terms: where you come from, how have you got from problem-based learning to the postdigital?

Maggi Savin-Baden (MSB): I first started using problem-based learning in about 1985, when I became a lecturer at Brunel. I was teaching occupational therapy and they were trying out problem-based learning with Barrows and Tamblyn's Problembased Learning: An Approach to Medical Education (1980), which was the only book in the world on problem-based learning. Some of the students liked problembased learning and some hated it, and we spent a lot of time trying to work out the scenarios. It wasn't my idea; it was Gaynor Sadlo's. I was always interested in learning because I failed so badly at school.

I'd started to do a postgraduate diploma in higher education at London University, one of the first ever in the UK. Having done that for two years, the person who'd been encouraging me said I should do a Masters and I thought, 'I'm not capable of that'. So, for my masters I did a mixed method study into students' experiences of problem-based learning and that's where it began. Then the same person said, 'Maggi, you should go on and do a PhD', and I went, 'erm right!'.

\footnotetext{
1 See https://www.springer.com/series/16439. Accessed 4 October 2021.

2 See https://www.ijme.net/. Accessed 4 October 2021.

3 See https://www.tcrecord.org/. Accessed 4 October 2021.

${ }^{4}$ See https://www.tandfonline.com/toc/cshe20/current. Accessed 4 October 2021.
} 
I began to explore different areas, and an anatomy tutor friend said, 'Maggi, why don't you do it in problem-based learning?' And I thought, 'well, why not?' I began to look around the UK. There were only five places using problem-based learning at the time, and four of them allowed me in. I ended up exploring mechanical engineering, automotive design engineering, nursing and social work. They were my four research sites, because that's all there was. I did a multi-site study. My supervisors were Susan Weil and Ron Barnett. Ron did a lot of the critical thinking work with me and really helped me to go on. My PhD was examined by Peter Jarvis from Adult and Continuing Education and Lewis Elton, who was Ben Elton's dad, ${ }^{5}$ and at the end of the viva Ron Barnett said to me, 'Maggi, you need to write this up as a book'. So, he encouraged me. I've had a lot of people who've supported me in terms of helping me to grow on, and I've tried to do that throughout my career, to 'pay it forward'. In 2000 I published my first book, Problem-based Learning in Higher Education: Untold Stories (Savin-Baden 2000), and I've done almost a book a year since then.

AMK: The first time I ever came across problem-based learning was as a student from the Far East at Glasgow University who was doing an EdD (professional doctorate) and was interested in doing a thesis in this area. At the time, I closely associated it with medicine.

MSB: Problem-based learning was originally developed in Canada. I think my book was the third book in the world on problem-based learning.

AMK: Problem-based Learning in Higher Education: Untold Stories (Savin-Baden 2000)?

MSB: There wasn't a lot of problem-based learning about, even in 2000, but it was really starting to take off. I researched problem-based learning because I was interested in learning. I was invited to run a session in Alabama, so I went over to Alabama, which was then a real shock to the system, and I'd been chatting with somebody called Claire Major. It was Claire who encouraged me to write an introductory text because there wasn't one at the time, and we ended up doing it together-we wrote Foundations of Problem-based Learning (Savin-Baden and Major 2004). Claire and I had a very fruitful five or six years of writing. The other passion for me was research methods. I've always enjoyed research methods and when I was living in Glenshee, Scotland, I used to teach research methods at Glasgow University in the evenings on a Monday night. I was encouraged by a colleague, Jean Barr, to write on research methods.

AMK: Oh, I know of Jean Barr. By the time I got to Glasgow she had long retired.

MSB: She was a great encourager and said, 'Maggi, come and do this stuff'. We used to sit in her office before I started teaching and debate research methods. So, in a way, that sparked me to do what Claire and I still call 'the big book, the big, fat textbook'. Qualitative Research: The Essential Guide to Theory and Practice (Savin-Baden and Major 2013) took a long time to get off the ground. We'd also both got into the idea of qualitative research synthesis, because we were

\footnotetext{
${ }^{5}$ Ben Elton is a very well-known British comedian, actor and screen-writer.
} 
really fed up with quantitative research synthesis and just decided that somebody needed to move away from the thing that was being called meta-ethnography and develop something different.

Claire and I both felt we were often in spaces of innovation where we saw problems with the existing literature and the way things were done and wanted to do it differently and better. The big research textbook was really supposed to be a one-stop for everything. It's got everything from how to do a literature review through how to analyse and interpret data.

AMK: Is there a relationship between problem-based learning and what you might call collaborative learning or cooperative learning?

MSB: I think there is. Problem-based learning, collaborative learning and experiential learning all are very similar in their approach. But a lot of the other ones are really lecturer-led, while problem-based learning has the emphasis on starting with a challenge or a problem for the students and the students driving the learning.

AMK: They're not supposed to be, though. If you do collaborative learning properly, it should not be lecturer or teacher-led.

MSB: No. Yet it often is, and it depends on the discipline. So, it's also the discipline-based pedagogy that comes into play.

AMK: I have a colleague here at Queen's University, Belfast, Professor Allen Thurston, whose research is in cooperative learning and peer tutoring (Thurston et al. 2021). Cooperative learning is very much structured around dividing students into small, task-based groups in which there is, for example, an instructor, and at least key assigned tasks, in which students must engage to ensure that everybody's participating in the learning process.

MSB: That's very much how problem-based learning works.

AMK: So, presumably the thinking behind it comes from Piagetian-type thinking, or Vygotskian constructivist learning?

MSB: The original argument from the medics in Canada at the time was that medical students could learn all this knowledge, but when you put a patient in front of them, they didn't know what to do, and it was like a rabbit in the headlights. So, the idea was to try and educate them in ways that would enable them to learn more effectively and to be able to apply their knowledge. I wouldn't have said it was particularly Piagetian but probably draws some influence from Vygotsky. Collaborative learning would fit, but my work is based more on experiential learning. I drew a lot on the work of Mesirow and Freire and later, hooks.

In Problem-based Learning in Higher Education: Untold Stories (Savin-Baden 2000), I theorised about how I thought problem-based learning should be located pedagogically and said it was more than just a practical means. I mean, a bit of Argyris and Schön (1991), reflective practitioner (Schön 1991), that kind of stuff, but the big thing for me was that a lot of people in engineering used to use it as a means of problem solving and my big argument all the way through was that problem-based learning is not about solving problems. It's about managing situations. So, I think that's the big one for me. But again, that's rehearsed at the beginning of my first book and I still stand by that argument, even now. 


\section{From Failure in School to Success at Learning}

AMK: In terms of how you described yourself as a bit of a failure in school, and that your father didn't expect you to go very far, what was it about problem-based learning that made such a difference for you?

MSB: I guess coming from being the major failure in the family of four children, I've fought my way through. I don't think my father, who was a headmaster, ever thought I would do anything much, and when I was the first in the family to get a $\mathrm{PhD}, \mathrm{I}$ think he was both proud and shocked. That's where my interest in learning came from. When I did this postgraduate certificate in higher education, we were all given a different group of people (to study) like critical theorists, the humanists or the cognitive behaviouralists. We were split into four groups and given literally a huge pile of articles, and were told that within a week, we'd have to come back and run a session based on the premise of the group of people we had been given to study.

AMK: Was that when you were doing your master's?

MSB: No. It was before that, so I was 26, 27. I was at London University getting my Diploma in Teaching and Curriculum Development in Higher Education. An awful lot of the sessions we did were problem-based in their approach. So, I began to realise that the reason I didn't learn at school was because I didn't learn the way I'd been taught. When I was 12 and 13 I used to ask questions like, 'Where do log tables come from and why does Pythagoras Theorem work?', and nobody would answer; they just said, 'just do it. Just get on with it'. I learnt that I was a questioner.

That was when I started to realise that it wasn't that I was stupid, but that I just didn't learn the way I was taught at school. So, because even though I only got three O Levels, ${ }^{6}$ they let me stay on in sixth form and do A Levels. The history teacher taught in a way that was research-based. So, I did well in history. I got a B in history, and everybody fell over and realised that perhaps I wasn't so stupid after all. I'd already got an unconditional place to do occupational therapy, which was great because it was a combination of arts and sciences, and that's what I did. I went to London for three years and then practiced, and always found myself in spaces of innovation.

I worked on the first ever HIV/AIDS ward, at University College Hospital London $\mathrm{UCH}$ ), and was the first occupational therapist on the oncology team. I was always doing innovative things. So, I was asked to go and work at Brunel and that's where I started teaching. I started my $\mathrm{PhD}$, and then I moved to the University of East Anglia to teach and was bullied, I think, because the head of department was threatened by me and then got postviral fatigue syndrome for 2 years. So we went up to Scotland where my husband ran an outdoor perusits centre, with me just recovering from postviral, and I sat in Glenshee overlooking the hillsides and finished my $\mathrm{PhD}$ and sent it off from Pitlochry Post Office.

\footnotetext{
6 This refers to subject-based school qualification in England, Wales and Northern Ireland sat by 16-year-olds which was replaced by General Certificate in Secondary Education in 1988. O Levels led to A Levels, which determine entry into Further and Higher Education.
} 
AMK: I know Pitlochry well.

MSB: Then having done the book, I started to be seen as somebody who knew something about problem-based learning. I started up a consultancy business based from home in Glenshee, Perthshire, and became a consultant to the Dundee School of Nursing and Midwifery, and went all over the UK, and then to Alabama, to run sessions and to speak. We came to Warwickshire, to Coventry University, and I went back into the School of Occupational Therapy, thinking, 'Oh, I'll just stay here for a couple of years'. But we had a new vice chancellor, Madeleine Atkins, and she was an educationalist who encouraged me to gain grant income. I got some research money with Jisc ${ }^{7}$ and St George's Medical School, University of London, to try and bring problem-based learning into the virtual world, Second Life. ${ }^{8}$ Having got about $£ 200 \mathrm{k}$ from Jisc, I got this big grant ( $£ 550 \mathrm{k}$ ) from Leverhulme to look at the impact of learning using problem-based learning and other approaches in virtual worlds like Second Life.

I got three PhD students, a research fellow, and some support from an admin person, and so the vice chancellor let run my own small-scale research unit. I carried on getting small amounts of money from various sources to do other bits of related research. At the same time, Claire Major and I were writing the book on qualitative research synthesis, An Introduction to Qualitative Research Synthesis: Managing the Information Explosion in Social Science Research (Major and Savin-Baden 2010). I was doing workshops in Sweden on Qualitative Research Synthesis at the same time and I still do keynotes.

\section{Chatbots, Virtual Humans and Digital Afterlives in Spaces of Innovation}

AMK: What was your research at the time showing about the value and the efficacy of problem-based learning?

MSB: I think just that it was a really flexible approach, and you could use it. We created simulations in virtual worlds. I worked with a company called Daden, ${ }^{9}$ who I still work with now, and I said to them, 'oh, could you create a pretend avatar like a chatbot that we could use, and the student won't know isn't a person?' It was almost a cross between a simulation and problem-based learning online. That prompted the book, A Practical Guide to Problem-based Learning Online (Savin-Baden 2007), about different forms of doing problem-based learning in different online spaces. To begin with, I thought to myself, 'why would anybody want to do problem-based learning online?'.

At that point I thought, 'well, I can't find anybody who's doing much on this'. I ferreted all my contacts around the world in problem-based learning and asked, 'is

\footnotetext{
7 Joint Information Systems Committee, Jisc, supports and promotes digital technologies in UK education and research. See https://www.jisc.ac.uk/about. Accessed 5 July 2021.

${ }^{8}$ See https://secondlife.com/. Accessed 5 July 2021.

9 See https://www.daden.co.uk/. Accessed 5 July 2021.
} 
anybody doing stuff online?' So, we had the combination of the how-to-do-it book in A Practical Guide (Savin-Baden 2007) and then the edited collection of people who were doing it, Problem-based Learning Online (Savin-Baden and Wilkie 2006). But again, it was one of those spaces of innovation where I just thought, 'well, I can't see anybody else is doing it, so why not?'.

Daden started doing work for the Ministry of Defence. They wanted us to create chatbots and also gave us some money to do trials. We did one trial with students about truth telling. We wanted to find out if the students would reveal more about alcohol and various other things to a chatbot than in a questionnaire. The men said they didn't say more to the chatbot than in the questionnaire, but actually they did tend to reveal more. That was the start of the development of the work on virtual humans.

That then moved to, well, what can we create? I think that was about 2015-2016, that we started to get more money from the Ministry of Defence, and we created things that we could test with squaddies (soldiers). We spent hours down at Lyneham researching peoples' views. We created different levels of chatbot. We called them a 'virtual mentor', 'virtual human', and a 'virtual persona'. The virtual mentor was just a little support bot, which we took on and tested last year at RAF Fylingdales, North Yorkshire, England, and moved it from web browsers onto people's mobile phones. The virtual human was a little bit more than that (virtual mentor). Then we developed the 'virtual persona', which the Ministry of Defence really thought was fantastic, and gave us even more money.

We had a colleague called Barry and we created a 'virtual Barry'. We took all his emails, all his personal data, all his stuff, and we created a face that would lipsynch. That sounds passé now, but it was quite innovative a few years ago. So, you could operate that, and you could ask Barry questions. I then said to David Burden at Daden, 'well, how does this relate to digital immortality to create a digital immortal?'. In 2017, I found a lawyer at Worcester, England, and then the three of us wrote this article about what we thought was possible and what the legal implications were. Only last week (April 2021), I was at a Death in the Law conference talking about this stuff.

Since then, I've been also asked to speak to Gloucester Diocese (Anglican Church of England) the William Temple Foundation, ${ }^{10}$ another faith-based community, and this weekend, I'm speaking at Christian in Science Conference about digital afterlife. Things moved from digital immortality to digital afterlife, because it just seemed to be a more fluid concept. Digital immortality assumes long-term definite existence, literal immortality, whereas afterlife is much more encompassing of what people choose to leave behind about their digital assets, their digital remains, as well as whether they choose to create a copy of themselves before they die. As a result of that, I've got interested in death-tech and what all the death...

AMK: I've never heard of these things!

${ }^{10}$ A charitable foundation which is interested in the impact of religion in public life. See https:// williamtemplefoundation.org.uk/about-the-foundation/. Accessed 5 July 2021. 
MSB: And also, the new one is cem-tech, which I just love, which is not about cement, it's about cemetery technology!

AMK: I don't want to talk about myself too much, but our own book in the Postdigital Science and Education series, The Epistemology of Deceit in a Postdigital Era: Dupery by Design (MacKenzie et al. 2021), was published just weeks after yours and I'm already thinking about the next one. I'm interested in the epistemologies of deceit and ignorance online. There's one section I think we should definitely have in the next book. There has to be discussions with respect to rights, death-tech and cem-technology, and our rights to our avatars and our virtual mentors. We can discuss this later.

Your trajectory is really fascinating. To go from problem-based learning as you did in the late 1990s and early 2000s to these kinds of very complex, I suppose, existential questions about our existence in the online environment. But, if I may, can you try and make the link between what you began your career with and where you are now. Is there still a role for problem-based learning in these kinds of issues?

MSB: I think there is. I haven't really explored it properly in relation to the postdigital, but I guess that's going to be the next learning book. I'm also writing a new version of $A$ Practical Guide to Problem-based Learning Online (Savin-Baden 2007) with acolleague who is doing her $\mathrm{PhD}$ with me. One of the things that's been quite interesting in Covid19 lockdown is the use of online learning and a realisation that you cannot sit there and do a one-hour lecture. You've got to rethink what learning means in online spaces, and equally, you have to understand what learning means in religious spaces (Reader and Savin-Baden 2021).

AMK: Absolutely. When you first began writing on problem-based learning, and, as you say, you've always worked in the spaces of innovation, you must have encountered many critics of your approach, or at least sceptics.

MSB: I was paid for an afternoon session with lawyers in East London, and they only lasted about an hour and a half because they thought it was a load of rubbish and they left. Another one was where I was in this palatial space in London talking to accountants, and I remember hearing myself say, 'do you think we could move the overhead projector screen, because the candelabra is in the way of it?' That summed it all up. They just sat there completely bemused.

AMK: Where do you think that scepticism comes from? Is it a result of what's done to us when we're in school, the individualised approach to learning, in the sense that you are there, you're the passive recipient of the knowledge the teacher is transmitting to you? To go back to your earlier example: a student asks, 'where does Pythagoras Theorem come from?', and the teacher replies, 'never mind that, just go and learn it'. This is rote, memorised learning, and it's not pleasurable, it's drudgery, it's very difficult to link discrete items of knowledge together in these highly abstract ways.

It's no wonder that students get switched off. But we assess how intelligent young students are on the basis of how much information they can memorise and then regurgitate what they have been taught. So, we turn the students into what I call 'regurgitants' rather than young people who are constructively, critically engaged in learning. It seems to me that the work that you have done over these past 20 or 30 years has demonstrated, again and again, the vitality of problem-based learning. 
MSB: I completely agree. I think we're still stuck in this government-guided, government-enforced, government-pushing, government-controlled, which is probably the best description, school learning. You can see it. I'm part of the School of Education now and you just see it. If there's going to be a check by the Office for Standards in Education, Children's Services and Skills (OFSTED), they're all running round like headless chickens. Heads of Department should be strong critical thinkers.

We need to stand up for our profession and our pedagogy: I was doing consultancy at Salford, and they asked, 'Maggi, what are we going to do when the professional body turns up and they say they don't like problem-based learning?' I said, 'well I'll be there if you like, but are you against it?' What a lot of these people say is, 'but in the regulations, it says duh, duh, duh, duh. We can't do this, we can't do that, we can't do the other'. I said, 'show me in the regulations where it says that'. Well, they couldn't find it because it was folklore. It's the same even in universities. We have aims and objectives which are behavioural. And I've been saying for years, I say it all the time still, we need to throw them out, we want learning intentions.

Thankfully, I work on a master's programme now, which has intentions of learning. It doesn't have outcomes. This is where people just don't understand philosophically that the language we use actually informs what we do. I don't think enough parents, or enough teachers or lecturers stand up to the system and say, 'this is not the way this should be, this is not what learning is'.

AMK: I wholeheartedly agree with you. I'm an educationalist and my background is in secondary school teaching ... On the one hand, you have educators who will talk about Piaget and Vygotsky, for example, and the significance of constructivist learning. Then the behavioural management kicks in, and you see this need for teachers to exercise control over the learning process and, therefore, over the children whom they are educating. Too many teachers go back to this transmissive model of education, which doesn't work for many young people. The so-called disruptive, the 'deviant', the kids who don't comply, they're not learning. And often, it's not because they're badly behaved kids, it's because the whole approach to their learning doesn't make any sense to them.

MSB: It didn't make any sense to me. I was taught by a lovely man when I was at London University doing my masters and he called it the 'myth of the BOK' (body of knowledge). That phrase has stayed with me. I liked and developed, as a result of this, my ideas on learning spaces, notions and modes of knowledge. The things that you don't teach, like when to keep silent and the virtue of tact, are key life skills in almost every profession. And yet, where do you find them in the curriculum?

AMK: You don't. I have a student who did a fascinating $\mathrm{PhD}$ on the use of silence in the classroom. Not by the teacher, by the students, and the ways in which they exercise silence in order to retain power, to retain autonomy, to keep intact their dignity and to prevent the teacher from invading their spaces. So my student developed a taxonomy of silence. But when she was talking to teachers about silence, the only terms under which they understood silence was control.

MSB: I'd love to see that taxonomy. Has she published it?

AMK: Yes, but she does not discuss the taxonomy, only the nature of silence and how it is used by young people in a learning setting (Hanna 2020). And of course, 
silence is always used, too, to either express boredom or to mask boredom because learning is not problem-based learning. They're trained to be regurgitants.

So, given what has happened during the Covid-19 pandemic, what are people now saying about the value of problem-based learning? Because it's very clear-we can educate online. It's not ideal, but it can be done and done effectively if we don't rely on the traditional didactic method or the asynchronous lecture. Or, it is a synchronous lecture, that we're not talking to the screen for an hour, or however long it might be.

MSB: I don't really know the answer to the question, but I know that within four or five months of being in lockdown, I had a meeting with the person who was doing the $\mathrm{PhD}$ with me, somebody from her university, and a few people from Worcester, all wanting to talk about how to do problem-based learning online effectively. Heather, who's doing the $\mathrm{PhD}$ with me, said, 'it's absolutely hilarious. I could easily buy a copy of A Practical Guide to Problem-based Learning Online (Savin-Baden 2007) two years ago and now you can't get them for love nor money'. And she said the price of the books has gone up. So, clearly there's some resonance there and certainly Routledge want us to do a new version.

AMK: When do you start working on the next version?

MSB: We'll start working in the next few months, but the book won't be out for eighteen months.

\section{Embodiment, Positioning and Power in the Online Environment- and Getting Stuck}

AMK: A Practical Guide to Using Second Life in Higher Education (2010) is full of great advice on how to use Second Life as a teacher and student. You say that 'second' life is a parallel to 'real' life and pose really interesting questions about the virtual environment. 'Being' in Second Life, you state,

prompts us and our students to engage with issues of embodiment and questions about positioning and power. For example, does it matter if: Students come to class as an animal or naked? Students stand, dance or walk off in the middle of a discussion? Students come to class carrying a gun? Students change their clothes while the teacher is speaking? (Savin-Baden 2010: 16).

How did you become involved in Second Life?

MSB: It was partly because the Practical Guide was written in 2010. I was asked to write this almost at the last minute as somebody else had dropped out of the writing project. Second Life was sold by Linden Labs in 2020 and, in the main, Second Life doesn't seem to be used in higher education much now. But people are taking some of the principles of virtual world learning and using it in gamification. I've been working with Michael Callaghan at University of Ulster on gamification and using it in Unity $3 \mathrm{D}^{11}$ and I think some of the principles in the book could be

${ }^{11}$ A platform that creates interactive, real-time content. See https://unity.com/. Accessed 4 October 2021. 
transferred into other forms of gamification and other kinds of virtual worlds, but in these cases, students wouldn't come to class as an animal. People would not generally tend to dance or walk in the middle of a discussion. Unity 3D is probably a much more controlled gamified environment, but that's work that's still developing.

I think worlds like Second Life did disrupt, and did create liminality. Some of the work that I wrote with Christine Sinclair (of Edinburgh University) relates to that sense of liminality in some of the explorations we had. I think things like gesturebased media and mixed reality are coming into the new forum of augmented and virtual reality. That's an area I'm beginning to explore at the moment with some new work from the Ministry of Defence funding about what counts as effective pedagogy for augmented and virtual reality.

AMK: From Second Life you moved to developing ideas on 'threshold concepts' (Savin-Baden and Tombs 2018). What stimulated this interest? And what do you mean by threshold concepts? Can you tell me why threshold concepts are necessary to problem-based learning? You then speak of liminal tunnels (ontological, rhizomatic and cognitive); what are these?

MSB: I've been really interested in threshold concepts since their inception in 2008 when I was working with Ray Land at Coventry University. To some extent, I disagreed with Ray about threshold concepts being cognitive, which was his then emphasis. I think threshold concepts are really important because they talk a lot about stuck places. That relates back to my problem-based learning $\mathrm{PhD}$, a lot of which focussed on students' sense of disjunction and getting stuck. In 1996, disjunction and getting stuck wasn't spoken about much in learning terms, though they were to some extent explored by Peter Jarvis and Jack Mezirow, but not much apart from that.

In 2008, threshold concepts really began to put getting stuck, moving on and shifting along on the map and relating learning to disciplinary differences. I think they've always been there in problem-based learning, and it was just due to some conversations, I think, with $\mathrm{PhD}$ students I was supervising and other people, that I got interested in exploring them. I began another one of these spaces of innovation and asked around to find out if people had experienced or had got data on threshold concepts in problem-based learning, and in many ways, the contributors to the book were the first people to really start to talk about that.

In terms of the liminal tunnels, that came out of some work I was doing with Angelica Fredholm and Charlotte Silén and their contributions to Threshold Concepts in Problem-based Learning (Savin-Baden and Tombs 2018). It was Angelica's $\mathrm{PhD}$ that started the discussions about liminal tunnels. I've since developed that work further on the use of liminal tunnels and the afterlife.

\section{Mind, Body and Communication in Online Environments}

AMK: The idea of a virtual human, to me, is an entirely fascinating one, and much of what I know about this comes from your work. How did you move from problem-based learning, threshold concepts, and research methods to 
virtual humans? What was your motivation in writing Virtual Humans: Today and Tomorrow (Burden and Savin-Baden 2019)?

MSB: In my earlier work with David Burden, I asked whether we could put a chatbot in the virtual world to see if the students would be hoodwinked by it and realise it wasn't a person. That was the link between problem-based learning and chatbots and virtual humans. The motivation for the book came from David, who'd always wanted to write one. He's a businessman, a signals engineer in the army which he left to set up his own business. I was quite keen, but I thought it would be a challenge to write with somebody who's not an academic writer. However, David had some interesting views, so he was the lead on this. His background in understanding the technology is second to none. He is a real leader in the field, and so he led on the topics on things like mind, body and communications.

AMK: You write that '[a] virtual human is a digital entity (or perhaps, more generally, a program, algorithm or even a process) which (looks) thinks, feels and behaves like a human' (Burden and Savin-Baden 2019: 16). Would you feel confident in offering a definition of 'artificial intelligence'?

MSB: I'm not sure either of us would offer a definition of intelligence because it's so culturally sensitive. This (idea) came from funding from the Ministry of Defence to develop chatbots and virtual humans-and also virtual persona. I think that the definition still stands, that artificial intelligence is an entity, or a programme, or an algorithm which behaves like a human being. I think the other thing central to this book was this understanding that artificial intelligence is machine learning, which it clearly isn't. We would argue strongly that artificial intelligence is much more than machine learning, and we set that out quite clearly at the beginning of the book.

AMK: You and David raise good questions about virtual ethics: what do you see as being the most important of these?

MSB: Ethics was much more my area. Your question is something I'd spent a lot of time considering and I'm not sure whether I would position one question over another. In the technological world I think is really important to recognise that ethics in the digital spaces are just the same as face-to-face ethics, a fact that needs to be discussed and published.

AMK: Digital immortality is defined as 'the continuation of an active or passive digital presence after death' (Burden and Savin-Baden 2019: 231). How is digital immortality changing the way we express grief and venerate the dead? Is death obsolete?

MSB: Well, I attend the artificial intelligence select committee at the House of Lords (the upper house of the Parliament of the United Kingdom), and that's certainly a continuing debate in that space. I talk about digital immortality at that point because in 2017, having created the chatbots, David and I had started discussing whether we could create something to leave behind (afterlife). So, I asked the question: 'can we create a copy of ourselves to leave behind?'.

The idea of the digital immortal came in 2017 and we wrote an article (Savin-Baden, Burden, and Taylor 2017) about that and then with a lawyer because we were concerned about the legalities of digital afterlives. That then led on to later work based on 
the creation of 'virtual Barry' chatbot with Ministry of Defence funding, and thereafter into two books on digital afterlife, Digital Afterlife: Death Matters in a Digital Age (Savin-Baden and Mason-Robbie 2020) and Digital Afterlife and the Spiritual Realm (Savin-Baden forthcoming 2022).

\section{Digital Immortality, or How the Dead Survive Online}

AMK: There is almost a seamless move from Virtual Humans (Burden and SavinBaden 2019) to the idea and ethical critique of what you term the Digital Afterlife (Savin-Baden and Mason-Robbie 2020). In Digital Afterlife you write that '[t]here is a need for ... understanding of how the dead, despite being dead, still survive in society' (Savin-Baden and Mason-Robbie 2020: 1). Further:

This reification also characterises the creation of Digital Afterlife as it is essentially treating the digital presence as if it is both a representation of the deceased person, but also that it in some way exists and has form beyond merely leaving behind letters, diaries, and personal effects. The growth of personality capture, mind uploading, and computationally inspired life after death have huge implications for the future of religion, understandings of the afterlife, and the influence of the dead surviving in society. Wagner $(2012$, p. 4) notes ' $[\mathrm{b}]$ oth religion and virtual reality can be viewed as manifestations of the desire for transcendence, the wish for some mode of imagination or being, that lies just beyond the reach of our ordinary lives'. (Savin-Baden and MasonRobbie 2020: 15)

MSB: I mentioned before that the interest in digital afterlife came partly through the work on virtual humans. It also came as a result of my increasing interest in being a funeral celebrant in the Church of England, and a realisation that, theologically, there was not much discussion happening in many faiths about digital afterlives - and not just within Christian faiths. The shift from mortality to digital afterlife_digital immortality — was largely because of the view that immortality is literal immortality, the idea that somebody is there ad infinitum, whereas digital afterlife encompasses everything from digital legacy, through digital remains, to creating a digital afterlife in terms of a persona.

You quoted me on the dead being dead in society. I think that's still very true. They live on in our phones, they live on in Facebook. What we're actually seeing is people creating copies of the deceased, Griefbots or Dadbots, which, for many people, goes beyond the whole idea of personality capture. There is this sense that people want to transcend death and I do think this is of concern. When you speak to funeral celebrants, there is concern about the care for people. In Covid-19, online funerals have been recorded. The cameras can get in the way of the burial, and the funeral directors can become chat show hosts. So, what we're seeing, then, is the shift of the sacred and the digital into a space into which they don't easily fit.

AMK: It has never occurred to me to think of these issues. Your work, it seems to me, is ground-breaking. How will the digital afterlife affect faith, faith rituals, mental health, and family relationships pre- and post-death? 
MSB: A lot of the answer to this is: we don't entirely know. If you look at different faiths, a lot of it depends on whether you're a Hindu, a Muslim, a Jew, a Christian, a Humanist, and where you believe you go after death. For some Christians, there's a belief that we journey alongside the living, the Communion of the Saints. For Buddhists who believe in reincarnation, they're not entirely sure whether it will affect their ability to progress. In terms of Hindus and Muslims, there is a worry that creating a digital afterlife, in terms of a persona, will affect both family relationships and, particularly I think for Muslims, progression after death. So, I think it's an area of concern.

There's also a bit of a worry about people keeping the phones of their dead loved ones, or burying them in the coffins, or choosing to bury them in different spaces. Sometimes they want to leave a hologram on the gravestone, or a QR code, which is not allowed in many graveyards. But there's also the ethics of what is left behind and the issue of where the choices are around that. A lot of people don't have a digital Will, and they don't have a digital executor, and so there are concerns about that as well.

AMK: This quote is intriguing: 'What is clear from considering the many perspectives shared in this book is that whilst a Digital Afterlife is a possibility for most of us due to our ongoing digital presence, immortality is only a theoretical possibility given the impossibility of empirical certainty. Essentially the foreverness of forever is in question.' (Savin-Baden and Mason-Robbie 2020: 200). What is postdigital theology and why should we be concerned about it?

MSB: The discussions in 2019-2020 resulted in Digital Afterlife: Death Matters in a Digital Age (Savin-Baden and Mason-Robbie 2020), and since then I have been asked to a short, accessible book AI for Death and Dying (Savin-Baden 2021a). I'm just finishing Digital Afterlife and the Spiritual Realm (Savin-Baden forthcoming 2022), which begins to get at some of the issues that I've been talking about. So, it doesn't just cover memorialisation, it covers religious understandings of eschatology, it looks at ambivalence and spectacle in death and the changing landscape, and the way that the digital is having an effect on that.

As a result of this interest, I've also been asked to edit a book by Petar Jandrić in the Postdigital Science and Education book series, on postdigital theology with the Reverend Dr John Reeder, because we're concerned that there isn't a sense of theology that is fluid and liquid and that is moving with the times. This book, titled Postdigital Theologies: Technology, Belief, and Practice (Reader and Savin-Baden forthcoming 2023), is now in the making.

So, postdigital theology is something that's essentially ungraspable. It's not post, as in the postmodern, but it's about the liquidity of the postdigital and the theology together. And yes, people do live on in their letters and biographies and films, but even those are being changed. People are inserting themselves into photographs of their grandparents; film stars are leaving a legacy which is then used to create a fund for those left behind as their digital presence is reused in films. So, there is a real sense of a different kind of memorialisation going on.

AMK: Privacy is also of considerable interest and concern. How can we protect this once a person has died; and indeed, the wishes of the bereaved who may want to maintain access to the digital memories of the deceased? 
MSB: There are some issues, I think, about post-mortem harm, and again, I think a lot of this depends on your belief system. If you ask a lot of Christian ministers, they don't really believe in post-mortem harm because they believe that the dead will be raised at the resurrection and therefore that harm is not possible. If you talk to lawyers, there is a sense that post-mortem harm can affect somebody's dignity and their reputation post-death. But legally, there's very little to cover this area at the moment, either in church law or in the British legal system.

We're supposed to be the leaders in artificial intelligence legislation in the UK, but for many of us, we still feel we're quite a long way behind. So, I don't know whether we can protect someone once they've died, or the wishes of the bereaved. If they want to ensure digital suicide, they need to do that before they die. Digital afterlife is a possibility, and we will live on, however much we've deleted, and I do think there is a foreverness of forever that exists as a result of what's going on in the digital world.

\section{Postdigital Humans}

AMK: For the novice reader approaching your work for the first time, how is she to understand what a 'postdigital' human is? Do conceptions of the postdigital trouble our various traditions of what it means to be human?

MSB: The postdigital human is seen as someone who can merge the old and the new, someone who can live with critical perspective and a collection of stances. Thus, she would be able to take a stance towards the digital which seeks to challenge the educational, economic, and ethical impact of digital technology on humanity and the environment.

AMK: How does Postdigital Humans: Transitions, Transformations and Transcendence (Savin-Baden 2021) differ from your earlier publications on the human? What do the authors seek to challenge? For example, the scientific and non-predatory nature of data and algorithms?

MSB: This volume argues that issues of the postdigital now take centre stage, and begins to deal with ethical concerns which be explored more fully in my next volume, Postdigital Learning and the $21^{\text {st }}$ Century University: A Critical Exploration of Digital Futures (Savin-Baden forthcoming 2023). For example, it is clear that many of the discussions about humans and machines in the 2020s should be focusing on automated decision making (ADM) drawing on Big Brother Watch ${ }^{12}$ and Algorithm Watch ${ }^{13}$ which expose and challenge threats to privacy, freedoms, and civil liberties amid technological change. ADM is an area that few academics in higher education have considered in-depth in terms of its impact on learning. Surveillance capitalism extends to the university too. Students and staff are tracked and managed through movements and behaviours and thus shape our behaviour towards guaranteed outcomes.

\footnotetext{
12 See https://bigbrotherwatch.org.uk/campaigns/stop-facial-recognition/. Accessed 5 October 2021.

13 See https://algorithmwatch.org/en/. Accessed 5 October 2021.
} 
AMK: Postdigital Humans (Savin-Baden 2021) is an edited collection. What would you say are the key threads that weave the chapters together?

MSB: What this text illustrates is that the development and use of postdigital humans is occurring rapidly, but often in unexpected ways and spaces. The chapters explore approaches to developing and using postdigital humans and the impact they are having on a postdigital world. The key thread the book explores are conceptions of postdigital humans, postdigital humans and education, philosophy, ethics and religion, current research, and practices at a time when education is changing rapidly with digital, technological advances. The authors outline the major challenges faced by today's employers, developers, teachers, researchers, priests and philosophers such as the possibility for using postdigital humans for teaching, training and practice.

AMK: Relatedly, you speak of the 'marketized diminishment of the human' (Savin-Baden 2021: xv). This is a powerful statement. Can you expand on your concerns here?

MSB: Whilst not dealt with in this volume (but will be in Savin-Baden 2023), my concerns focus on postdigital ethics and the impact of postdigital learning on the environment. Whilst following the Covid-19 pandemic people are being encouraged to travel less, there is little exploration of the ethics of the hardware universities use, the questionable manufacturing conditions in China, Kenya, and elsewhere, and the creation of the iSlaves of the twenty-first century. Postdigital ethics challenges us to rethink ethics so that it not about prescription before actions (à la ethics committees) but is instead an emergent porous and ongoing series of ethical decisions and practices.

AMK: Are you, your contributors, optimistic that we can retain control of our autonomy and agency in the virtual world, indeed, that we can challenge injustice as ineffectively as we do in the non-virtual world?

MSB: I am not sure we are challenging or having an impact on injustice in any sphere at the moment, sadly.

AMK: Finally, Maggi, I can't imagine that you will stop at these books. What can we look forward to reading from you next?

MSB: In Butler-Kisber, Keefe, and Savin-Baden Stories of Displacement (forthcoming 2022) we focus on a variety of displacement experiences in different cultures and contexts. Displacement refers to the forced movement of a person, or people, from their locality or environment and/or occupational activities. The book situates narrative inquiry in the landscape of qualitative work, classifies it in a series of constellations and, at the same time, provides readers with thirteen displacement stories which cut across disciplines.

In Postdigital Theologies: Technology, Belief, and Practice (Reader and SavinBaden forthcoming 2023), we explore ideas, theories and research relating to postdigital theologies. It is already well researched that digital technology has an impact on the practical areas of ministry and mission within religious institutions. However, the relationships between technologies and the actual content of belief and practice have received much less attention. For that reason, the book explores, for example, themes concerned with where is God to be found or present in the postdigital condition? What are the implications of the postdigital for spirituality and indeed for the activity of God through the Holy Spirit? And, how do concepts of transhumanism or posthumanism effect understandings of the incarnation? 
AMK: Thank you, Maggi, for engaging in these conversations about the postdigital with me. It has been a pleasure and a source of fascination to engage with your work.

MSB: Thank you.

\section{References}

Burden, D., \& Savin-Baden, M (2019). Virtual Humans: Today and Tomorrow. Boca Raton, FL: Taylor and Francis.

Butler-Kisber, L., Keefe, K. C., \& Savin-Baden, M. (forthcoming 2022). Stories of Displacement. London: Routledge.

Hanna, A. (2020). Silence at School: Silence, Respect, and (In)justice. Doctoral Thesis. Belfast: Queen's University Belfast.

MacKenzie, A., Rose, J., \& Bhatt, I. (Eds.). (2021). The Epistemology of Deceit in a Postdigital Era: Dupery by Design. Cham: Springer.

Major, C., \& Savin-Baden, M. (2010). An Introduction to Qualitative Research Synthesis: Managing the Information Explosion in Social Science Research. London: Routledge.

Reader, J., \& Savin-Baden, M. (2021). Postdigital Theologies: Technology, Belief and Practice. Postdigital Science and Education, 3(3), 679-685. https://doi.org/10.1007/s42438-020-00212-6.

Reader, J., \& Savin-Baden, M. (forthcoming 2023). Postdigital Theologies: Technology, Belief, and Practice. Cham: Springer.

Savin-Baden, M. (2000). Problem-based Learning in Higher Education: Untold Stories. Buckingham: Open University Press and SRHE.

Savin-Baden, M. (2021). Artificial Intelligence, Death and Dying. Boca Raton, FL: Taylor and Francis.

Savin-Baden, M. (2007). A Practical Guide to Problem-based Learning Online. London: Routledge.

Savin-Baden, M. (2010). A Practical Guide to Using Second Life in Higher Education. Maidenhead: McGraw Hill.

Savin-Baden, M. (2021a). AI for Death and Dying. Boca Raton, FL: Taylor and Francis.

Savin-Baden, M. (Ed.). (2021b). Postdigital Humans: Transitions, Transformations and Transcendence. Cham: Springer.

Savin-Baden, M. (forthcoming 2022). Digital Afterlife and the Spiritual Realm. London: Routledge.

Savin-Baden, M. (forthcoming 2023). Postdigital Learning and the $21^{\text {st }}$ Century University: A Critical Exploration of Digital Futures. London: Routledge.

Savin-Baden, M., \& Major, C. (2004). Foundations of Problem-based Learning. Maidenhead: Open University Press and SRHE.

Savin-Baden, M., \& Major, C. (2013) Qualitative Research: The Essential Guide to Theory and Practice. London: Routledge.

Savin-Baden, M., \& Mason-Robbie V. (Eds.). (2020). Digital Afterlife: Death Matters in a Digital Age. Boca Raton, FL: Taylor and Francis.

Savin-Baden, M., \& Wilkie, K. (Eds.), (2006). Problem-based Learning Online. Maidenhead: McGraw Hill.

Savin-Baden, M., Burden., \& Taylor, H. (2017). The Ethics and Impact of Digital Immortality. Knowledge Cultures, 5(2), 11-29. https://doi.org/10.22381/KC52201711.

Savin-Baden, M., \& Tombs, G. (Eds). (2018). Threshold Concepts in Problem-based Learning. Rotterdam: Sense.

Schön, D. (1991). The Reflective Practitioner: How Professionals Think in Action. Abingdon and Oxon: Routledge.

Thurston, A., Cockeril, M., \& Chiang, T. H (2021). Assessing the Effects of Differential Peer Tutoring for Tutees and Tutors. Education Sciences, 11(3), 97. https://doi.org/10.3390/educsci11030097.

Wagner, R. (2012). Godwired: Religion, Ritual and Virtual Reality. Abindon and Oxon: Routledge. 